\title{
マグネトロンスパッタリング法による耐食・耐摩耗窒化クロム膜の創製
}

\section{Fabrication of Chromium nitride Coatings with High Wear and Corrosion Resistance by Magnetron sputtering}

\author{
○ 窪田佳彦（福井大院） \\ 木内淳介（アイテック） \\ 真柄宏之（福井県工業技術センター） \\ 佐治栄治（福井県工業技術センター） \\ 吉長重樹（福井大） \\ 正 本田知己（福井大） \\ 正 岩井善郎（福井大）
}

Yoshihiko KUBOTA, Shigeki YOSHINAGA, Tomomi HONDA, Yoshiro IWAI,

University of Fukui, Bunkyo3-9-1, Fukui-shi, Fukui, 910-8507

Jyunsuke KIUCHI, EYETEC Co.,Ltd., Kaminaka-cho2-6-8, Sabae-shi, Fukui, 916-0016

Hiroyuki MAGARA, Eiji SAJI;

Industrial technology center of Fukui, Kawaiwasizuka-cho61 aza-Kitainada10, Fukui-shi, Fukui, 910-0102

Key Words: Chromium nitride coating, Magnetron sputtering, Wear, Corrosion

\section{1. 緒言}

スパッタリング法やイオンプレーティング法で成膜され る Cr-N 膜は, 工業的に多用されている Ti-N 膜と比較して硬 度はやや低いが, 熱膨張係数が小さく優れた耐食性と低摩 擦・耐摩耗性を示すとされ[1]，しゅう動部品・自動車部品人 の適用が増えている. 一般に, 薄膜の物理的, 化学的又は機 械的な特性はその材質によって決まるが，同じ材質の薄膜で も，成膜条件によってその特性が変わることはしばしばある． それは薄膜の特性自体が薄膜のモルフォロジーや結晶配向 性に影響されるからである. 従って薄膜の特性を制御するた めには, 成膜条件と薄膜のモルフォロジ一や結晶配向性との 関係を把握する必要がある[2].

本研究では, 成膜条件の異なる $\mathrm{Cr}, \mathrm{Cr}-\mathrm{N}$ 膜の耐食・耐摩 耗性を調べるために, 皮膜の諸特性に及ぼす各成膜条件の影 響を調査した. Cr, Cr-N 膜を成膜する基材には SUS304 を用 いた. 成膜法は, 他の成膜法と比べて(1)薄膜材料の種類を問 わない(2)高品質の薄膜が作製できる(3)制御性が非常に良い

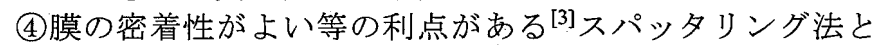
した.

\section{2. 実験装置及び方法}

マグネトロンスパッタリング装置(ヒラノ光音株製 HK-3S 型)を用いて, SUS304 の基材に Cr, Cr-N 膜を成膜した。 タ ーダットには純度 $4 \mathrm{~N}(99.99 \%) の \mathrm{Cr}$ を使用した. 前処理とし て, アルカリ脱脂, 電解脱脂, 酸中和, 純水洗浄を行った. スパッタガスには市販のアルゴンガス及び窒素ガスを用い た. 成膜方法は以下の通りである. 基材を冷却機構が装備さ れたホルダーに取り付け，3元スパッタ処理部を $2 \times 10^{-3} \mathrm{~Pa}$ 程度まで排気する. アルゴンガス圧力 $5.0 \mathrm{~Pa}$, 出力 $400 \mathrm{~W}$ に て 5 分間高周波逆スパッタリング処理を行った後, 雲囲気ガ ス(アルゴンガス, 窒素ガス)圧力を一定状態としクロムター ゲット直上にて成膜する. スパッタ時の雰囲気ガス中のアル ゴンガスと窒素ガスの流量割合(A)や成膜時間(B)を変化させ た. 成膜条件を Table 1 に示す.

$\mathrm{Cr} ， \mathrm{Cr}-\mathrm{N}$ 膜の組成を分析するために，X 線回折装置(株)島 津製作所製 XRD-6100，以下，XRD と表記)を用いた。基材 からの回折を避けるため低角入射 X 線回折法を用い; X 線管 球 $\mathrm{Cu}$, 管電压 $40 \mathrm{kV}$, 管電流 $40 \mathrm{~mA}$, 入射角度 $1^{\circ}$ の条件で 分析した.

硬さ測定には，超微小押し込み硬さ試験機(侏)エリオニク
ス製 ENT1100)を用いた，圧子は稜間隔 $115^{\circ}$ の三角錐圧子を 用いた．押し込み荷重は基材に影響されず，表面の粗さの影 響もほとんど受けない $3.92 \mathrm{mN}$ とした。試験は 7 回行い, 最 大值と最小值を除く 5 点の平均から硬さを求めた。

皮膜の欠陥評価には，電気化学測定装置(北斗電工侏製 HZ-3000)を用い, ドライコーティング膜の欠陷評価法(臨界 不働態化電流密度法)に準拠して評価を行った。溶液には, $0.5 \mathrm{~mol} \mathrm{H}_{2} \mathrm{SO}_{4}$ と $0.05 \mathrm{~mol} \mathrm{KSCN}$ の混合液を用い, 溶液温度を プレートヒーターにより $30^{\circ} \mathrm{C}$ に保持した. また, 試験前に 60 分間アルゴンガスを $400 \mathrm{ml} / \mathrm{min}$ 以上流して脱気した. 参 照電極には飽和カロメルを用い，電位走査速度を $0.20 \mathrm{mV} / \mathrm{s}$ にして, 測定電圧- $0.45 \mathrm{~V}$ から+0.40 V まで電位を掃引した。

摩耗試験は, 本研究室独自の方法である MSE(Micro Slurry-jet Erosion)式摩耗試験法 ${ }^{[4]}$ によって行った。水槽内で 攪汼したスラリーを, 吸水口から吸い上げてノズル内を通る ように循環させる.エアコンプレッサで加圧した空気をノズ ルに送り，ノズル内にあるスラリーに空気を押し当てて加速 させ，ノズル端から噴射させる. 衝突させる固体粒子には平 均粒子直径 $\mathrm{d}=1 \mu \mathrm{m}$ の不定形アルミナ粒子を用いた. スラリ 一濃度 3 wt.\%, 噴射圧力 $0.5 \mathrm{MPa}$, 衝突角度 $90^{\circ}$ で試験を行 った. 摩耗量は, 摩耗深さで評価した。摩耗面の形状を触針 式粗さ計で測定し, 処女面からの最大深さを求め, これを摩 耗深さとした。

Table 1 Coating conditions

\begin{tabular}{c||c|c}
\hline \hline Sputtering conditions & $\mathrm{A}$ & $\mathrm{B}$ \\
\hline Film thickness, $\mu \mathrm{m}$ & $2^{-0.36}$ & $\begin{array}{c}0.67,0.85,1.60 \\
2.15,3.56\end{array}$ \\
\hline Atmospheres gas pressure, & \multicolumn{2}{|c}{0.50} \\
\hline Substrate power supply & \multicolumn{2}{|c}{$\mathrm{DC}$} \\
\hline Substrate voltage, $\mathrm{V}$ & \multicolumn{2}{|c}{100} \\
\hline Cathode power supply & \multicolumn{2}{|c}{$\mathrm{DC}$} \\
\hline Cathode output, $\mathrm{W}$ & \multicolumn{2}{|c}{500} \\
\hline The rate of $\mathrm{N}_{2}$ gas & $0,13,30$, & \multirow{2}{*}{70} \\
in atmosphere gas, $\%$ & 70,100 & \\
\hline \hline
\end{tabular}

\section{3. 実験結果及び考察}

\section{3-1 皮膜の物理的特性に及ぼす各成膜条件の影響}

窒素ガス流量割合

Table 1 の成膜条件 A に示すように, 窒素ガス流量割合を 変化させて成膜した $\mathrm{Cr}, \mathrm{Cr}-\mathrm{N}$ 膜の XRD 結果を Fig.1 に示す. 
窒素ガス流量割合 $0 \%$ ときは, 当然 $\mathrm{Cr}$ のピークのみ検出 された．窒素ガス流量割合が増加すると共に皮膜は $13 \%$ の 時に $\mathrm{Cr}_{2} \mathrm{~N}$ に，それ以降 $\mathrm{CrN}$ へと変化した．窒素ガス流量割 合が $100 \%$ の膜の回折ピークは他の膜と比べてやや幅の広い 回折ピークを示すようになった. 30 \%以降, $\mathrm{CrN}$ の各ピーク が窒素ガス流量割合の増加と共に低角度側へシフトしてい る.このことは, 窒素ガス流量割合の増加とともに窒素原子 の比が増加して CrN 膜の格子定数が大きくなることを意味 している.

成膜時間(膜厚)

Table 1 の成膜条件 B に示すように, 成膜時間(膜厚)を変化 させ成膜した CrN 膜の XRD の測定結果を Fig.2 に示す. 膜 厚が増加しても $\mathrm{CrN}$ 膜の配向性はほぼ一定であった．膜厚 $0.67 \mu \mathrm{m}$ 注成膜初期の状態を, $3.75 \mu \mathrm{m}$ は成膜が進んだ状態を 表すので, 本研究での成膜条件では $\mathrm{CrN}$ 膜は結晶の配向がほ ぼ一定のまま成長することがわかった。

\section{3-2 皮膜の機械的特性に及ぼす各成膜条件の影響}

欠陷量

膜厚と最大電流密度の関係を Fig.3 に示す. 成膜条件によ らず, 膜厚の増加に伴い最大電流密度が減少した。これは, 膜厚が増すことで基材まで達する皮膜の欠陥の量が減少す るためである.

皮膜の硬さ・押乙込み弾性率

窒素ガス流量割合と皮膜の押し込み弾性率に対する硬さ の比の関系を Fig.4 に示す．押し込み弾性率は皮膜のヤング 率とほぼ同じと考えてよく, 窒素ガス流量割合が増加すると 皮膜の押し込み弹性率に対する硬さの比は増加し, 窒素ガス 流量割合 $70 \%$ の皮膜でピークを示した.

○耐摩耗性

窒素ガス流量割合と膜の摩耗率の関係を Fig.5 に示す。窒 素ガス流量割合 $13 \%$ 以降, 摩耗率は低下し, 窒素ガス流量 割合 $70 \%$ で最小となった。

\section{4. 結言}

1. 窒素ガス流量割合により，皮膜の組成・結晶状態は変 化するが，欠陷量に大きな変化は見られない。また，皮膜の 押し込み弾性率と硬さの比は $70 \%$ \%最大となり，摩耗率は $70 \%$ で最小となった.

2. 成膜時間を長くすることで，膜厚が厚くなり，欠陷量 が少なくなるが，摩耗率には影響しない。

本研究は, 文部科学省 都市エリア産学官連携促進事業「福 井まんなかエリア」の一環として実施された.ここに記して 謝意を表する.

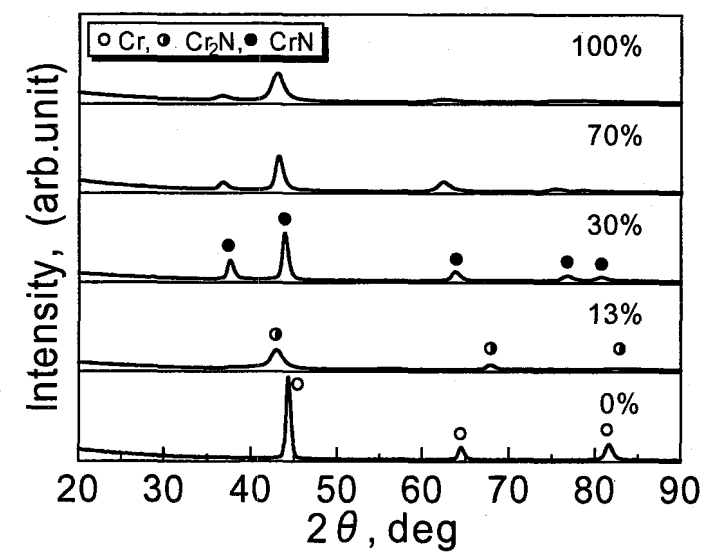

Fig.1 X-ray diffraction patterns of chromium nitride coatings deposited at different $\mathrm{N}_{2}$ gas flow-to-total gas flow ratio $\left(\mathrm{F}_{\mathrm{N}_{2}} / \mathrm{F}_{\text {total }}\right)$.

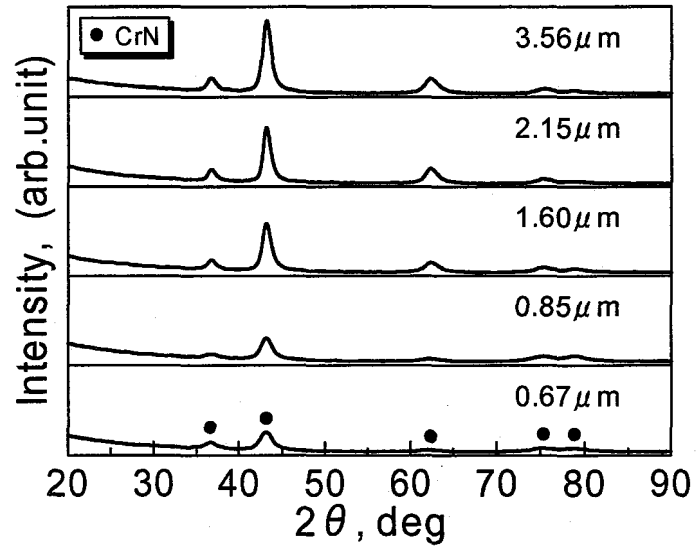

Fig.2 X-ray diffraction patterns of chromium nitride coatings deposited at different coating thickness.

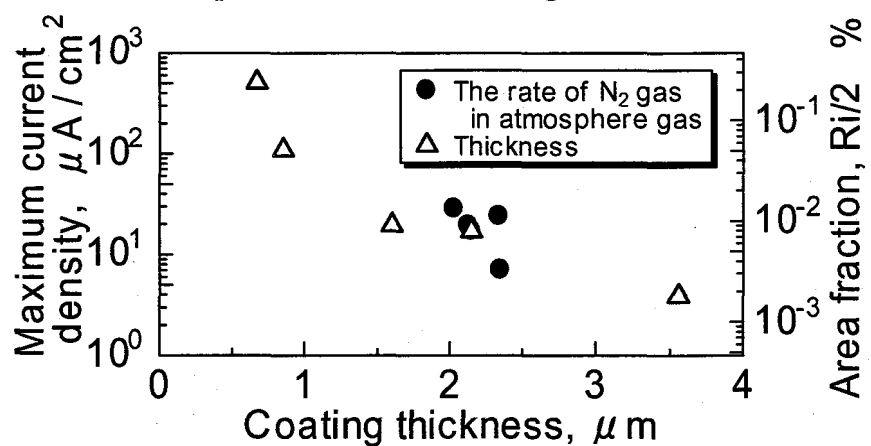

Fig.3 Relationship between maximum current density and coating thickness.

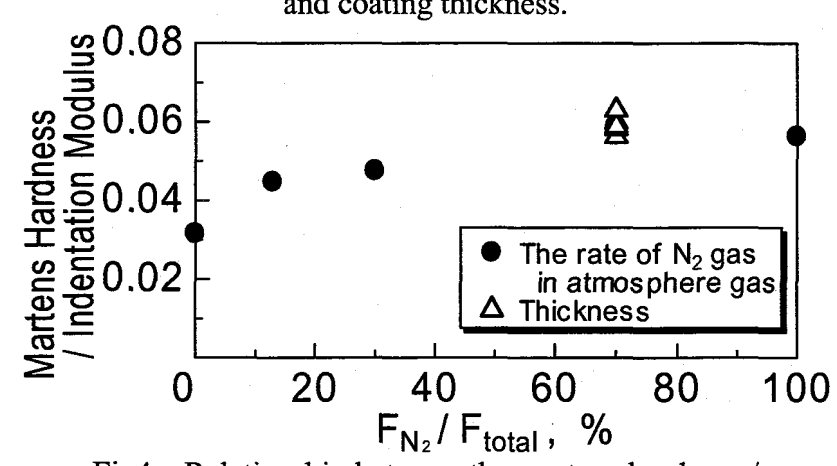

Fig4 Relationship between the martens hardness / indentation modulus and the $\mathrm{F}_{\mathrm{N}_{2}} / \mathrm{F}_{\text {total }}$.

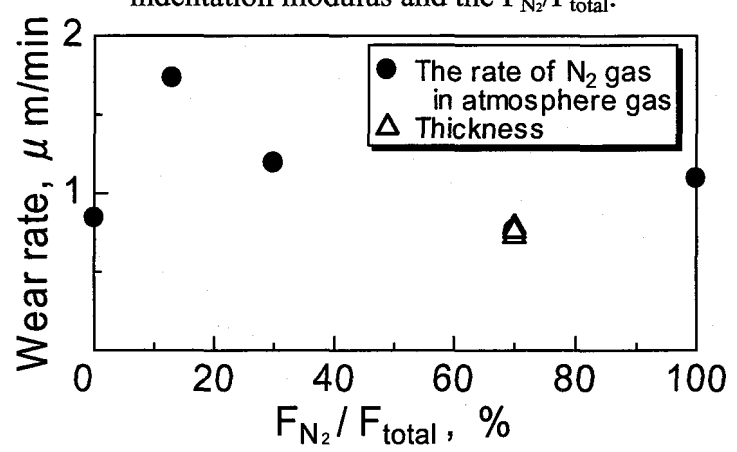

Fig.5 Relationship between wear rate and the $\mathrm{F}_{\mathrm{N}_{2}} / \mathrm{F}_{\text {total }}$.

\section{参考文献}

[1] 井手, 恵良, 岸武. 日本金属学会誌. 65(6), 2001, 502-508.

[2] 王，沖. 表面技術. 41(8)，1990，823-828.

[3] 大脇, 多賀ほか. 21 世紀板 薄膜製作応用ハンドブック. 權田俊一監修. 2003, p306.

[4] Y.Iwai, et al, WEAR, 251(2001), 861-867. 